\title{
Diverse proteomic alterations in gastric adenocarcinoma
}

\author{
Qing-Yu He ${ }^{1,2}$, Yim Hing Cheung ${ }^{2,3}$, Siu Tsan Yuen ${ }^{4}$, Suet Yi Leung ${ }^{4}$, Kent-Man Chu ${ }^{5}$ \\ and Jen-Fu Chiu, 3 \\ ${ }^{1}$ Department of Chemistry \\ ${ }^{2}$ Open Laboratory of Chemical Biology of the Institute of Molecular Technology for Drug \\ Discovery and Synthesis \\ ${ }^{3}$ Institute of Molecular Biology \\ ${ }^{4}$ Department of Pathology \\ ${ }^{5}$ Department of Surgery, University of Hong Kong, Hong Kong, China
}

Gastric adenocarcinoma is one of the most common cancers in Asian countries including China. Although its incidence rates in the West are lower than that in Asia, gastric cancer is still a major health problem worldwide, being second only to lung cancers in the number of deaths it causes. Helicobacter pylori infection has been identified as the major pathogen, but the detailed pathogenesis of gastric carcinoma remains elusive. Due to the lack of suitable and specific biomarkers for early detection, most cases of the disease are diagnosed at late stages and the survival rate is low. In this study, we used a proteomic approach to globally analyze the protein profiles of paired surgical specimens of primary gastric adenocarcinoma and nontumor mucosa aiming at identifying specific disease-associated proteins as potential clinical biomarkers and for carcinogenetic study. Compared to nontumor tissues, multiple protein alterations were found in tumor tissues. Some of these alterations involve variations in the expression of cytoskeleton proteins, including an increase in cytokeratin 8 and tropomyosin isoform and a decrease in cytokeratin 20. Coup-regulations of heat-shock proteins and glycolytic enzymes were observed in tumor tissues, indicating self-protective efforts of cells and the growing energy requirement during malignant transformation. Diverse regulations also occurred with proteins involved in cell proliferation and differentiation, such as GMP reductase 2 and creatine kinase $B$, and proteins bearing potential tumor suppressor activities, including prohibitin and selenium binding protein 1. More interestingly, a human stomach-specific protein, $18 \mathrm{kDa}$ antrum mucosa protein, was found to be dramatically under-expressed in cancer tissues, implicating a possible special pathological role for this protein in gastric carcinogenesis. Further comprehensive evaluation by globally considering the altered factors may result in the discovery of a biomarker index for effective assessment of the disease and may provide in-depth information for better understanding the pathogenesis of gastric cancer.

Keywords: Gastric cancer / Protein profiling / Tumor biomarkers / Two-dimensional gel electrophoresis

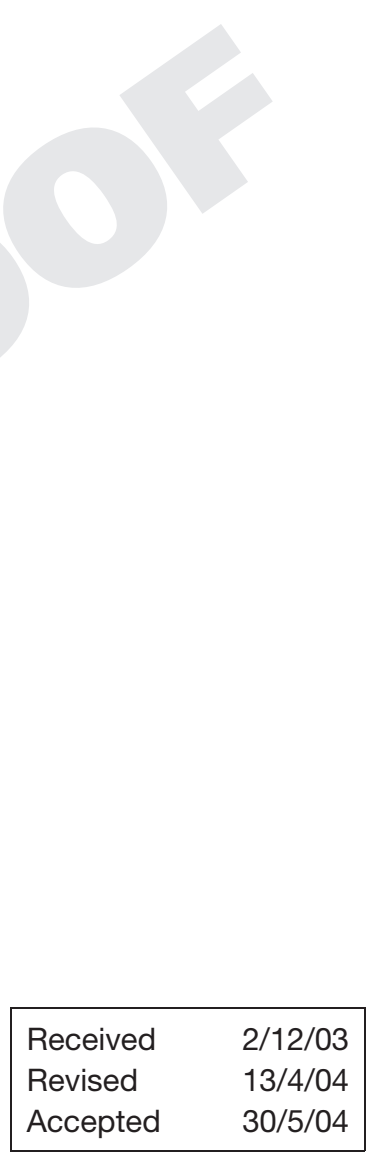

Correspondence: Dr. Qing-Yu He, Department of Chemistry, University of Hong Kong, Pokfulam, Hong Kong, China

E-mail: qyhe@hku.hk

Fax: +852-2817-1006

Abbreviations: $\alpha 1-A T$, alpha1-antitrypsin; AMP-18, $18 \mathrm{kDa}$ antrum mucosa protein; ApoA1, apolipoprotein A1; CA, carbonic anhydrase; CCT, chaperonin containing TCP1; CK, cytokeratin; CK-B, creatine kinase B; EF-Tu, translation elongation factor EFTu; GMPR, GMP reductase 2; HSP, heat-shock protein; PDI, protein disulfide isomerase; PGM, phosphoglycerate mutase 1; PK, pyruvate kinase; SeBP, selenium binding protein 1; TPI, triosephosphate isomerase

\section{Introduction}

Gastric cancer is a common malignant tumor, representing the second major cause of cancer related deaths worldwide [1-3]. Gastric adenocarcinoma constitutes approximately $90 \%$ of all gastric cancers. Helicobacter pylori-induced chronic gastritis has been recognized as the major risk for the development of gastric cancer [4, 5]. However, gastric carcinogenesis is a multistep process and the molecular mechanism of this carcinogenesis process remain unclear. Clinically, surgical resection is 
still the best choice, but it works only for patients with small and early cancer lesions. Unfortunately, most patients are diagnosed at an advanced stage and thus have a very low five-year survival rate (less than 10\%) [6]. This is partially due to lacking specific and sensitive biomarkers for diagnosis and monitoring of disease progress. The most frequently used gastric tumor markers, carcinoembryonic antigen and CA19-9, are far from satisfactory in terms of sensitivity and only a modest proportion of patients with gastric cancer has elevated levels of these proteins.

Proteomic analysis is a powerful technology used to comprehensively inspect protein expression in bodily fluids, tissues and cells [7-9]. By comparing the proteomic profiles between a healthy or control sample and a diseased or drug-treated sample, proteins altered in their expression levels and patterns can be identified and characterized. This approach is useful especially in the discovery of disease-associated proteins which change in expression and modification corresponding to a disease condition. These disease-related proteins can be used as biomarkers for diagnosis and disease monitoring and as targeted proteins for further mechanistic studies. Proteomic technology has been extensively utilized in biomarker discovery in various diseases [10-12]. However, only a limited number of proteomic studies have involved the identification of tumor-associated proteins in gastric cancer, although proteome databases of gastric tissue [13] and cell lines [14] have been constructed. So far, most attention has focused on identifying specific proteins or antigens that reflect the chemo- and thermo-resistant properties of stomach cancer $[15,16]$ and that are associated with $\mathrm{H}$. pylori [17, 18]. During the preparation of this manuscript a brief report was published, describing a proteomic approach to identify several proteins altered in gastric cancer [19]. In the current study, more clusters of altered proteins in gastric carcinoma were found to be associated with tumorigenesis. A correlation between the functions of these proteins and their expression in gastric cancer may provide useful information for identifying specific biomarkers or marker indexes with a potential clinical value and for better understanding the carcinogenesis of the disease.

\section{Materials and methods}

\subsection{Materials}

All enzymes and chemicals were purchased from either Sigma (St. Louis, MO, USA) or Fluka (Buchs, Switzerland). Antibody against $18 \mathrm{kDa}$ antrum mucosa protein (AMP-18) was generously donated by Dr. T. Martin from the University of Chicago; this is an antisera sample that also contains antibodies to some Escherichia coli proteins.

\subsection{Tissues and sample preparation}

Primary gastric adenocarcinoma and their adjacent nontumor mucosae were collected from 10 gastrectomy specimens from Queen Mary Hospital, The University of Hong Kong, Hong Kong, China. Tissues were snap-frozen in liquid nitrogen and stored in a deep freezer $\left(-80^{\circ} \mathrm{C}\right)$ until use. The study was approved by the ethics committee of the University of Hong Kong. The study included eight male and two female patients, whose ages ranged from 52 to 90 years. All tumors were intestinal type tumors according to Lauren's classification reference Detailed clinico-pathological data including tumor stage (according to the AJCC system), site, differentiation, and histological data on the tissue samples are listed in Table 1. Areas of tumor with purity more than $70 \%$ were chosen after assessment by cryostat sectioning for protein extraction. The nontumor mucosae were dissected free of muscle wall in fresh state, and confirmed by cryostat section before protein extraction. Figure 1 is a representative histological picture showing a pair of matched tissue samples side by side. For 2-DE, protein extraction from tissues was carried out following the procedure described previously [20]. For enzyme activity assessment, tissue extracts were prepared according to a published method [21]. Briefly, tissue was washed in cold physical saline $(0.9 \% \mathrm{NaCl})$ twice and homogenized in 2 volumes w/v of cold $20 \mathrm{~mm}$ Tris- $\mathrm{HCl}$ buffer, $\mathrm{pH} 7.5$, containing $1 \mathrm{~mm}$ EDTA and $1 \mathrm{~mm} \beta$-mercaptoethanol with a Pellet Pestle Motor (Kimble/Kontes, NJ, USA) for 1 min over ice. Cellular debris was removed by centrifugation at $4^{\circ} \mathrm{C}$ for $30 \mathrm{~min}$ at $12600 \times g$ and the supernatant was collected for enzyme activities. Protein concentrations were determined by the Bradford method, using BSA as a standard.

\section{$2.32-D E$}

2-DE was carried out with Amersham Biosystems (Uppsala, Sweden) IPGphor IEF and Ettan Dalt $\mathbf{a}$ city, country $\square$ six electrophoresis units by following the protocol described previously [22]. Protein samples $(50 \sim 100 \mu \mathrm{g})$ extracted from the tumor center and surrounding histologically normal mucosa were applied to the 2-DE $(13 \mathrm{~cm})$ and run in pairs side by side. Electrophoresis was performed in triplicate for each pair of samples to ensure reproducibility. All gels were visualized by silverstaining [22]. 
Table 1. Patients' information and histological data for the tissue samples used

\begin{tabular}{|c|c|c|c|c|c|c|c|c|c|}
\hline $\begin{array}{l}\text { Patient } \\
\text { code }\end{array}$ & Sex/age & $\begin{array}{l}\text { Tumor } \\
\text { site }\end{array}$ & $\begin{array}{l}\text { Normal } \\
\text { mucosa } \\
\text { site }\end{array}$ & T stage & $\begin{array}{l}\text { Sample } \\
\text { pairs }\end{array}$ & $\begin{array}{l}\text { Tumor } \\
\text { cells (\%) }\end{array}$ & $\begin{array}{l}\text { Normal } \\
\text { mucosal } \\
\text { cells (\%) }\end{array}$ & $\begin{array}{l}\text { Muscle } \\
\text { cells (\%) }\end{array}$ & $\begin{array}{l}\text { Connective tissue cells } \\
\text { lymphocytes, vessel cells, } \\
\text { fibroblast (\%) }\end{array}$ \\
\hline SX390 & $\mathrm{F} / 90$ & antrum & body & pT3N3 & $\begin{array}{l}\text { Tumor } \\
\text { Nontumor }\end{array}$ & $\begin{array}{r}95 \\
0\end{array}$ & $\begin{array}{r}0 \\
95\end{array}$ & $\begin{array}{l}0 \\
0\end{array}$ & $\begin{array}{l}5 \\
5\end{array}$ \\
\hline SX426 & M/72 & antrum & body & pT2NO & $\begin{array}{l}\text { Tumor } \\
\text { Nontumor }\end{array}$ & $\begin{array}{r}90 \\
0\end{array}$ & $\begin{array}{r}0 \\
95\end{array}$ & $\begin{array}{l}0 \\
0\end{array}$ & $\begin{array}{r}10 \\
5\end{array}$ \\
\hline SX437 & $\mathrm{M} / 62$ & antrum & body & pT3N3 & $\begin{array}{l}\text { Tumor } \\
\text { Nontumor }\end{array}$ & $\begin{array}{r}95 \\
0\end{array}$ & $\begin{array}{r}0 \\
95\end{array}$ & $\begin{array}{l}0 \\
0\end{array}$ & $\begin{array}{r}10 \\
5\end{array}$ \\
\hline SX452 & $M / 63$ & antrum & body & pT2N2 & $\begin{array}{l}\text { Tumor } \\
\text { Nontumor }\end{array}$ & $\begin{array}{r}75 \\
0\end{array}$ & $\begin{array}{r}5 \\
90\end{array}$ & $\begin{array}{l}5 \\
0\end{array}$ & $\begin{array}{l}15 \\
10\end{array}$ \\
\hline SX471 & M/66 & antrum & body & pT3N3 & $\begin{array}{l}\text { Tumor } \\
\text { Nontumor }\end{array}$ & $\begin{array}{r}70 \\
0\end{array}$ & $\begin{array}{r}0 \\
95\end{array}$ & $\begin{array}{l}5 \\
0\end{array}$ & $\begin{array}{r}25 \\
5\end{array}$ \\
\hline SX409 & $\mathrm{M} / 79$ & body & antrum & pT3N2 & $\begin{array}{l}\text { Tumor } \\
\text { Nontumor }\end{array}$ & $\begin{array}{r}90 \\
0\end{array}$ & $\begin{array}{r}0 \\
90\end{array}$ & $\begin{array}{l}0 \\
0\end{array}$ & $\begin{array}{l}10 \\
10\end{array}$ \\
\hline SX415 & M/85 & body & antrum & pT2NO & $\begin{array}{l}\text { Tumor } \\
\text { Nontumor }\end{array}$ & $\begin{array}{r}90 \\
0\end{array}$ & $\begin{array}{r}0 \\
70\end{array}$ & $\begin{array}{r}0 \\
10\end{array}$ & $\begin{array}{l}10 \\
20\end{array}$ \\
\hline SX423 & $\mathrm{M} / 56$ & body & antrum & pT3N2 & $\begin{array}{l}\text { Tumor } \\
\text { Nontumor }\end{array}$ & $\begin{array}{r}80 \\
0\end{array}$ & $\begin{array}{r}0 \\
90\end{array}$ & $\begin{array}{r}10 \\
0\end{array}$ & $\begin{array}{l}10 \\
10\end{array}$ \\
\hline SX442 & $\mathrm{M} / 82$ & body & antrum & pT3N1 & $\begin{array}{l}\text { Tumor } \\
\text { Nontumor }\end{array}$ & $\begin{array}{r}80 \\
0\end{array}$ & $\begin{array}{r}0 \\
90\end{array}$ & $\begin{array}{l}0 \\
0\end{array}$ & $\begin{array}{l}20 \\
10\end{array}$ \\
\hline SX453 & $F / 52$ & body & antrum & pT3N1 & $\begin{array}{l}\text { Tumor } \\
\text { Nontumor }\end{array}$ & $\begin{array}{r}75 \\
0\end{array}$ & $\begin{array}{r}0 \\
80\end{array}$ & $\begin{array}{r}5 \\
10\end{array}$ & $\begin{array}{l}20 \\
10\end{array}$ \\
\hline
\end{tabular}

Relative percentage (\%) of cells was rounded up to $5 \%$, cells less than $5 \%$ were counted as 0 as the number was too small.

Normal mucosa

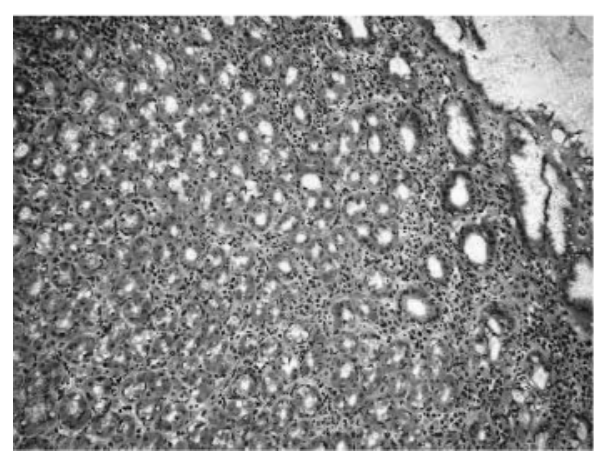

Gastric adenocarcinoma

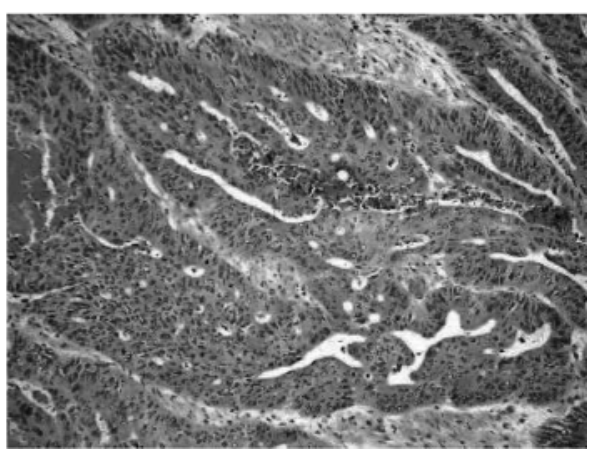

Figure 1. Representative histological pictures of normal gastric mucosa and gastric adenocarcinoma used for the proteomic study.

\subsection{Image analysis and MS peptide sequencing}

Image acquisition and analysis were performed with an ImageScanner (Amersham Biosciences) and ImageMaster 2D Elite software (Amersham Biosciences) [22]. Comparisons were made between gel images of tumor and matched nontumor samples pair by pair. Normalized volume differences were statistically calculated for all ten cases. Consistently and significantly different spots were selected for analysis by MALDI-TOF MS. Protein spots were cut out of gels in small pieces and subjected to ingel tryptic digestion overnight [22]. Peptide mass spectra were recorded and parameters for spectra acquisition were used as stated previously [22]. In database protein matching using MS-Fit (http://prospector.ucsf.edu/), mass accuracies with 25 ppm error or better and MOWSE scores over 300 were obtained in most of the analyses. Duplicate or triplicate runs were made to ensure an accurate analysis. 2-D Western blotting was performed to confirm the specificity of the identified proteins if necessary. 


\subsection{2-D Western blotting}

Protein samples were run on 2-D gels using the identical conditions as stated for 2-DE in Section 2.4. The separated proteins in the corresponding areas of the gels were transferred onto polyvinylidene fluoride membranes and incubated overnight at $4^{\circ} \mathrm{C}$ with a blocking buffer containing Tris-buffered saline, 0.1\% Tween 20 (TBST) and $5 \%$ nonfat dry milk. Membranes were washed with TBST and incubated with monoclonal or polyclonal antibodies at a 1:500 or 1:1000 dilution for $1 \mathrm{~h}$ at room temperature or overnight at $4^{\circ} \mathrm{C}$. After washing again with TBST, the membranes were blotted with a secondary antibody conjugated with horseradish peroxidase at a 1:10 000 dilution for $1 \mathrm{~h}$, and then detected with enhanced chemiluminescence (Pierce, Rockford, IL, USA) for $1 \mathrm{~min}$.

\subsection{Enzyme activity assessment}

Enzyme activity was determined by using a UV-Vis spectrophotometer. The absorbance of the final product converted by target enzyme was read against time. Methods for determination of enzyme activity previously documented [21, 23-25] were used to evaluate activities of triosephosphate isomerase (TPI), enolase and phosphoglycerate mutase (PGM). Wavelength was set at $340 \mathrm{~nm}$ with a $1 \mathrm{~cm}$ light path. The assay mixture was equilibrated at $25^{\circ} \mathrm{C}$ for $15 \mathrm{~min}$ and tissue extract was added just prior to measurement. Enzyme activities were expressed as $\mathrm{U} / \mathrm{g}$ protein ( 1 Unit $=1 \mu \mathrm{mol}$ substrate converted per minute).

\subsection{Immunohistochemistry staining}

Immunodetection of AMP-18 was performed using a polyclonal (rabbit) antihuman AMP-18 antibody (1:1000 dilution, kind gift from Dr. T. Martin). After heat mediated antigen retrieval, sections were incubated with primary antibody at $4^{\circ} \mathrm{C}$ overnight. Sections were then incubated with peroxidase-labeled (goat) antirabbit Ab (EnVision+; DAKO, Glostrup, Denmark), and developed with 3,3-diaminobenzine (Sigma), yielding a brown-colored signal.

\section{Results}

\subsection{Protein separation and identification}

Protein separation was performed in nonlinear $13 \mathrm{~cm} 2-D$ gels with $\mathrm{p} /$ ranges of 3-10 and $M_{\mathrm{r}}$ ranges of $6-200 \mathrm{~K}$. Figure 2 is an image overview for typical master gels of gastric tumor and nontumor tissues side by side. Around 1300 protein spots were well-separated in the gels. Highlighted in circles are those areas where significant and consistent alterations of protein expression were identified. These altered proteins distributed evenly throughout the entire gel, indicating that multiple clusters of proteins are involved in the process of tumorigenesis of gastric cancer. Table 2 lists all of the proteins identified through peptide fingerprinting matching, together with their accession numbers, fold differences in expression and $p$ values for the protein alterations in gastric cancer. These proteins can be classified into several categories based
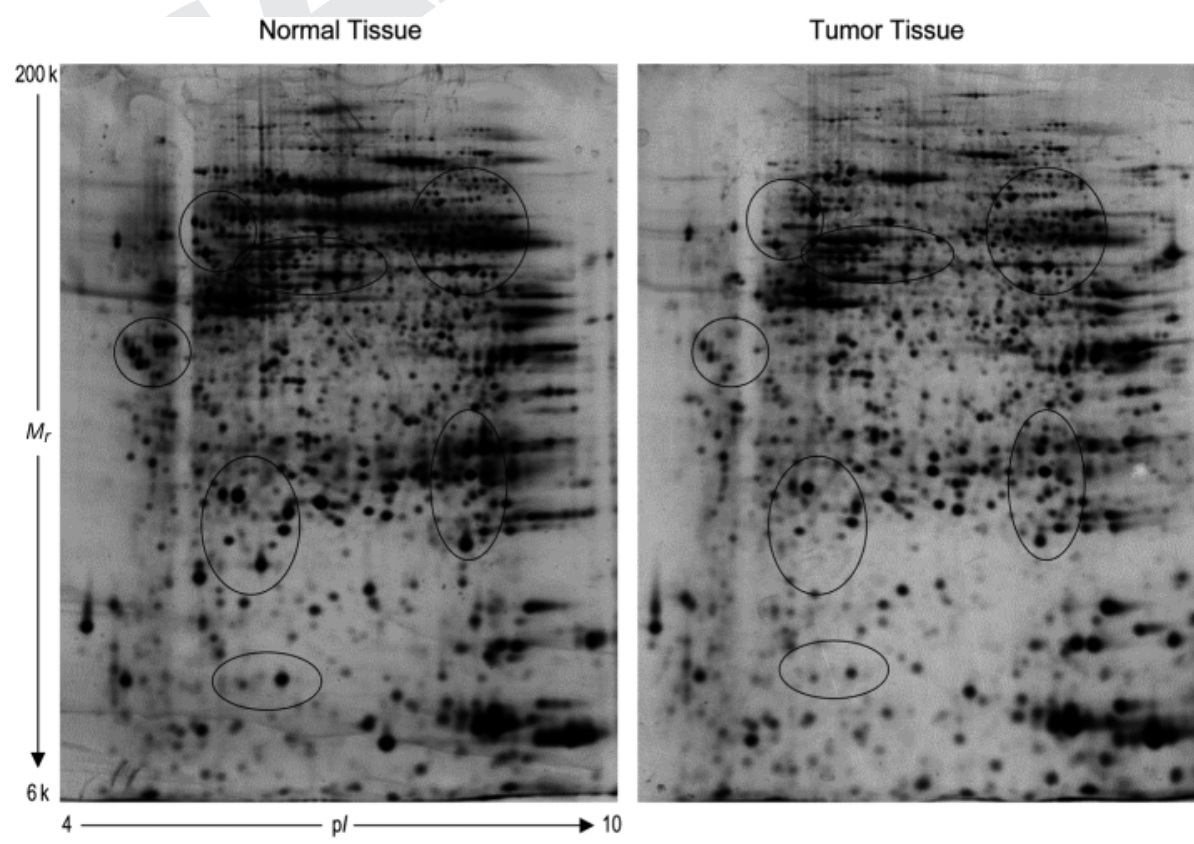

Figure 2. An overview of the master 2-D gel images for gastric adenocarcinoma and nontumor tissues. Highlighted in circles are the areas where significant and consistent differences were found in protein expression levels.

(C) 2004 WILEY-VCH Verlag GmbH \& Co. KGaA, Weinheim www.proteomics-journal.de 
Table 2. Proteins and their alterations in gastric cancer tissues

\begin{tabular}{|c|c|c|c|c|c|}
\hline Protein ID $\left(M_{\mathrm{r}} / \mathrm{p} /\right)$ & $\begin{array}{l}\text { Experimental } \\
\left(M_{\mathrm{r}} / \mathrm{p} /\right)\end{array}$ & $\begin{array}{l}\text { Acc \# } \\
\text { (NBCl) }\end{array}$ & Reported function & $\begin{array}{l}\text { Change } \\
\text { (fold) }\end{array}$ & $P$ value \\
\hline Cytokeratin 8 (CK8), (54 kD/5.5) & $55 \mathrm{kD} / 5.5$ & 2506774 & Cytoskeleton protein of intermediate filaments & +3 & 0.0023 \\
\hline Cytokeratin 20 (CK20), (48 kD/5.5) & 50 kD/5.5 & 547750 & Cytoskeleton protein of intermediate filaments & -2 & 0.0107 \\
\hline Tropomyosin isoform (TPM), (29 kD/ 4.8) & $30 \mathrm{kD} / 4.6$ & 9508585 & Cytoskeletal microfilament binding protein & +2 & 0.0056 \\
\hline Enolase $1,(47$ kD/7.0) & 48 kD/7.0 & 693933 & Glycolysis & +2 & 0.0003 \\
\hline Triosephosphate isomerase (TPI), (27 kD/6.4) & $26 \mathrm{kD} / 6.5$ & 136060 & Glycolysis & +2.5 & 0.0021 \\
\hline Phosphoglycerate mutase 1 (PGM), (29 kD/6.7) & $30 \mathrm{kD} / 6.6$ & 130348 & Glycolysis & +2.5 & 0.0052 \\
\hline Pyruvate kinase (PK), (58 kD/8.0) & $56 \mathrm{kD} / 8.0$ & 478822 & Glycolysis & +3.5 & 0.0093 \\
\hline Chaperonin containing TCP1 (CCT), (58 kD/6.2) & $60 \mathrm{kD} / 6.2$ & 627402 & Stress-related, chaperone & +2 & 0.0016 \\
\hline Heat shock protein 60 (HSP60), (61 kD/5.7) & $60 \mathrm{kD} / 5.5$ & 129379 & Stress-related, chaperone & +3 & 0.0009 \\
\hline $\begin{array}{l}\text { Heat shock cognate } 71 \text { protein (HSP70), } \\
\quad(71 \mathrm{kD} / 5.4)\end{array}$ & $70 \mathrm{kD} / 5.5$ & 123648 & Stress-related, chaprone & +2 & 0.0085 \\
\hline Protein disulfide isomerase (PDI), (57 kD/6.2) & $55 \mathrm{kD} / 6.3$ & 2135267 & Chaperone, isomerase, and redox activities & +1.5 & 0.0099 \\
\hline $\begin{array}{l}\text { Translation elongation factor EF-Tu (EF-Tu), } \\
\text { (49 kD/7.7) }\end{array}$ & $50 \mathrm{kD} / 7.4$ & 7443384 & $\begin{array}{l}\text { Translation factor, cell growth, chaperone } \\
\text { activity }\end{array}$ & +1.7 & 0.0133 \\
\hline Alpha-1-antitrypsin ( $\alpha 1-A T),(47$ kD/5.4) & $51 \mathrm{kD} / 5.2$ & 15990507 & Acute phase protein & -2 & 0.0045 \\
\hline Apolipoprotein A-1 (ApoA1), (31 kD/5.6) & $30 \mathrm{kD} / 5.7$ & 4557321 & Acute phase protein & -1.8 & 0.0039 \\
\hline $\begin{array}{l}\text { GMP reductase } 2 \text { (GMPR) (Fragment), } \\
\quad(38 \mathrm{kD} / 6.8)\end{array}$ & 22 kD/7.1 & 25008511 & Promote monocytic differentiation & -2 & 0.0011 \\
\hline Creatine kinase B (CK-B), (43 kD/5.3) & $42 \mathrm{kD} / 5.2$ & 180570 & Proliferation-transformation, energy buffering & -1.6 & 0.0071 \\
\hline Selenium binding protein 1 (SeBP), (52 kD/5.9) & $51 \mathrm{kD} / 6.0$ & 16306550 & Detoxification, inhibition of pre-malignantial cells & -2 & 0.0008 \\
\hline Prohibitin, $(30 \mathrm{kD} / 5.6)$ & $30 \mathrm{kD} / 5.4$ & 4505773 & Tumor suppressing, inhibition of cell proliferation & +1.8 & 0.0017 \\
\hline Carbonic anhydrase I (CA-I), (29 kD/6.6) & $31 \mathrm{kD} / 7.0$ & 115449 & $\mathrm{CO}_{2}$ hydration for intermediate metabolism & -2.5 & 0.0006 \\
\hline Carbonic anhydrase II (CA-II), (29 kD/6.9) & $31 \mathrm{kD} / 7.1$ & 115456 & $\mathrm{CO}_{2}$ hydration for intermediate metabolism & -5 & 0.0005 \\
\hline $\begin{array}{l}18 \mathrm{kDa} \text { Antrum mucosa protein (AMP-18), } \\
(22 \mathrm{kD} / 5.9)\end{array}$ & $20 \mathrm{kD} / 6.0$ & 26000208 & Human stomach-specific, epithelial cell mitogen & -19 & 0.0001 \\
\hline
\end{tabular}

Fold changes were calculated based on the image analysis of silver-stained gels.

on their functions, including cytoskeleton proteins, stress-related and chaperoning proteins, acute-phase proteins, glycolytic enzymes, enzymes involved in metabolism and cell proliferation, tumor suppressor proteins and stomach specific proteins. Table 3 summarizes parameters and residues of identified peptides in peptide fingerprinting matching for protein identifications. Most database matching has a very low total mass error $(<25$ ppm) and high overall MOWSE score ( $>300$ ). For proteins with low score matching, Western blotting with specific antibodies was performed to confirm the identification of the proteins.

\subsection{Protein alterations in gastric cancer}

Diverse protein alterations were first identified in cytoskeleton proteins between tumor and nontumor tissues from the same patients. Both cytokeratin (CK) 8 and tropomyo- sin isoform were significantly up-regulated in tumor samples, whereas CK20 had decreased expression in tumor tissues (Fig. 3). Substantial co-overexpression of glycolytic enzymes in tumor tissues indicates increased energy consumption during tumorigenesis in gastric cancer (Fig. 4). The increased glycolytic enzymes include enolase, TPI, PGM and pyruvate kinase (PK). The enzymatic activities of these proteins are also higher in tumor tissue than in nontumor tissues which corresponds to higher protein expression in tumor tissue (see below).

Another observation corresponding to the pathological feature of gastric cancer is the alterations of stressrelated and acute-phase proteins (Fig. 5). While the stress proteins that have molecular chaperone activity, including chaperonine containing TCP1 (CCT), heat-shock protein (HSP) 60, HSP70, protein disulfide isomerase (PDI) and translation elongation factor EF-Tu protein (EF-Tu) were up-regulated, acute-phase proteins including alpha1- 
Table 3. Results of MALDI-TOF mass spectra and database searching for protein identification

\begin{tabular}{|c|c|c|c|c|c|}
\hline Protein & Residues of identified peptides & $\begin{array}{l}\text { Peptides } \\
\text { matched }\end{array}$ & $\begin{array}{l}\text { Sequence } \\
\text { coverage }(\%)\end{array}$ & $\begin{array}{l}\text { Total mass } \\
\text { error }(\mathrm{ppm})\end{array}$ & $\begin{array}{l}\text { MOWSE } \\
\text { score }\end{array}$ \\
\hline Cytokeratin 8 (CK8) & $\begin{array}{l}\text { 9-18, 24-32, 97-110, 102-110, 161-176, } \\
\text { 186-198, 187-198, 187-198 (1Met-0x), } \\
\text { 199-213, 199-213 (1Met-0x), 214-225, } \\
\text { 226-233, 234-252, 253-264 (1Met-ox), } \\
\text { 253-273, 253-273 (1Met-0x), 265-273, } \\
\text { 274-295, 276-295 }\left(1 \mathrm{PO}_{4}\right), 286-301, \\
\text { 303-312, 313-325 }\left(1 \mathrm{PO}_{4}\right), 313-328, \\
317-328,329-341,329-347,329-347\left(\mathrm{PO}_{4}\right), \\
\text { 329-352, 342-352, 353-362, 370-381, } \\
\text { 370-381 (pyroGlu), 393-414, 394-414, } \\
394-414 \text { (1Met-ox), 470-483, }\end{array}$ & 36 & 59 & 20 & $1.16 e+06$ \\
\hline Cytokeratin 20 (CK20) & $\begin{array}{l}\text { 29-42, 104-112, 104-112 (pyroGlu), 113-122, } \\
\text { 116-122, 116-132, 129-140, 133-140, } \\
\text { 150-156, 150-163, 157-166, 157-166 (1P04), } \\
\text { 159-166, 179-187, 207-217, 244-252 } \\
\text { (pyroGlu), 244-252 (1P0 }), 253-263,264-280, \\
\text { 281-290, 281-291, 363-372, 381-392, } \\
\text { 402-411 }\left(\mathrm{PP}_{4}\right)\end{array}$ & 24 & 39 & 19 & $4.55 \mathrm{e}+05$ \\
\hline Tropomyosin isoform (TPM) & $\begin{array}{l}1-12 \text { (AcetN), 13-27, 14-27, 14-30, 31-40, } \\
\quad 41-54,41-55,43-55,56-69,66-76,117-131 \\
\quad 156-169,224-230\end{array}$ & 13 & 45 & 20 & 336 \\
\hline Enolase 1, (47 kD/7.0) & $\begin{array}{l}1-9,6-15,33-50,33-56,90-105,121-132 \\
184-193,200-221,203-221,240-262 \\
254-269,270-281,404-412,413-420 \\
413-426,427-434\end{array}$ & 16 & 41 & 14 & 5325 \\
\hline $\begin{array}{l}\text { Triosephosphate isomerase } \\
\text { (TPI) }\end{array}$ & $\begin{array}{l}7-14,86-99,100-113,101-113,132-149 \\
\text { 136-149, 143-149, 150-160, 176-188, } \\
\text { 176-190, 191-206, 195-206 }\end{array}$ & 12 & 38 & 31 & 6524 \\
\hline $\begin{array}{l}\text { Phosphoglycerate mutase } 1 \\
\text { (PGM) }\end{array}$ & $\begin{array}{l}11-21,22-39,22-40,84-90,87-100 \\
91-100,91-106,107-116,118-138 \\
118-138 \text { (1Met-0x), 181-191, 241-251 }\end{array}$ & 12 & 41 & 18 & $5.08 \mathrm{e}+05$ \\
\hline Pyruvate kinase (PK) & $\begin{array}{l}\text { 74-89, 267-278, 271-279, 368-376, } \\
\text { 384-399, 448-455, 448-461 }\end{array}$ & 7 & 12 & 22 & 632 \\
\hline $\begin{array}{l}\text { Chaperonin containing } \\
\text { TCP1 (CCT) }\end{array}$ & $\begin{array}{l}105-117,105-117 \text { (pyroGlu), 142-153, } \\
242-251,266-272,450-465\end{array}$ & 6 & 10 & 24 & 359 \\
\hline Heat shock protein 60 (HSP60) & $61-72,97-121,134-142,302-309,353-359$ & 5 & 10 & 15 & 172 \\
\hline $\begin{array}{l}\text { Heat shock cognate } 71 \text { protein } \\
\text { (HSP70) }\end{array}$ & $37-49,57-72,138-155,221-236,300-311$ & 5 & 11 & 16 & 345 \\
\hline $\begin{array}{l}\text { Protein disulfide isomerase } \\
\text { (PDI) }\end{array}$ & $\begin{array}{l}\text { 62-73, 63-73, 105-119, 130-146, 131-146, } \\
\text { 131-147 (pyroGlu), 174-183, 259-271, } \\
\text { 330-344, 333-347, 336-344, 336-347, } \\
\text { 352-363, 364-379, 434-448 (1Met-ox), } \\
\text { 483-496 }\end{array}$ & 16 & 28 & 17 & 7446 \\
\hline $\begin{array}{l}\text { Translation elongation factor } \\
\text { EF-Tu (EF-Tu) }\end{array}$ & $\begin{array}{l}92-105,94-105,94-107,95-105,95-107 \\
\text { 108-123, 166-172, 239-252, 312-327, } \\
316-327,352-366,422-429\end{array}$ & 12 & 20 & 12 & 1376 \\
\hline Alpha-1-antitrypsin ( $\alpha 1-A T)$ & $\begin{array}{l}\text { 46-60, 191-203, 191-203 (pyroGlu), 229-236, } \\
\quad 310-316,310-317\end{array}$ & 6 & 10 & 15 & 165 \\
\hline Apolipoprotein A-1 (ApoA1) & $\begin{array}{l}37-51,48-64,52-64,121-131,132-140 \\
141-155,143-157,185-195,185-197 \\
213-219,231-239\end{array}$ & 11 & 35 & 12 & 2739 \\
\hline
\end{tabular}

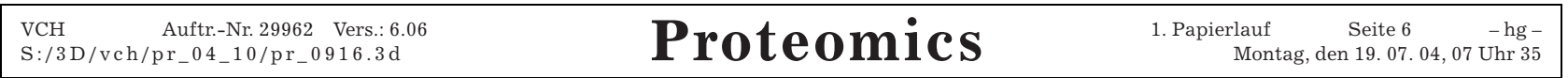


Table 3. Continued

\begin{tabular}{|c|c|c|c|c|c|}
\hline Protein & Residues of identified peptides & $\begin{array}{l}\text { Peptides } \\
\text { matched }\end{array}$ & $\begin{array}{l}\text { Sequence } \\
\text { coverage }(\%)\end{array}$ & $\begin{array}{l}\text { Total mass } \\
\text { error }(\mathrm{ppm})\end{array}$ & $\begin{array}{l}\text { MOWSE } \\
\text { score }\end{array}$ \\
\hline $\begin{array}{l}\text { GMP reductase } 2 \\
\quad \text { (GMPR) (Fragment) }\end{array}$ & $\begin{array}{l}\text { 216-232, 267-278, 267-278 (1Met-ox), 267-278 } \\
\text { (2Met-ox), 267-279, 267-279 (2Met-ox) }\end{array}$ & 6 & 8 & 30 & 1556 \\
\hline Creatine kinase B (CK-B) & $\begin{array}{l}12-32,14-32,33-43,33-45,108-130,157-172, \\
243-252,308-314,321-341,359-366,367-381\end{array}$ & 11 & 35 & 14 & $8.88 e+05$ \\
\hline $\begin{array}{l}\text { Selenium binding protein } 1 \\
\text { (SeBP) }\end{array}$ & $\begin{array}{l}1-20,35-52,104-114,104-117,161-174 \\
246-254,277-289,334-344,358-370 \\
412-419,449-460\end{array}$ & 13 & 27 & 13 & $1.74 \mathrm{e}+05$ \\
\hline Prohibitin & $\begin{array}{l}\text { 84-93, 106-117, 134-143, 187-195, 187-197, } \\
\text { 187-197 (pyroGlu), 198-207 }\end{array}$ & 7 & 19 & 10 & 625 \\
\hline Carbonic anhydrase I (CA-I) & $\begin{array}{l}\text { 1-19 (AcetN), 59-77, 78-90, 82-90, 115-128, } \\
\text { 215-228, 229-253 }\end{array}$ & 7 & 39 & 19 & $2.94 \mathrm{e}+04$ \\
\hline Carbonic anhydrase II (CA-II) & $\begin{array}{l}\text { 1-24 (AcetN), 10-24, 40-58, 59-76, 59-80, } \\
\text { 114-126, 133-148, 227-251 }\end{array}$ & 8 & 45 & 28 & 4993 \\
\hline $\begin{array}{l}18 \text { kDa Antrum mucosa protein } \\
\text { (AMP-18) }\end{array}$ & $\begin{array}{l}\text { 86-102, 86-102 (1Met-ox), 86-102 (2Met-ox), } \\
\text { 89-102, 89-102 (1Met-0x), 89-104, } \\
\text { 89-104 (1Met-0x), 89-105, 89-105 (1Met-ox), } \\
\text { 106-117, 110-133, 110-133 (1Met-ox), 118-133, } \\
\text { 118-133 (1Met-0x), 118-136, 118-136 (1Met-ox) }\end{array}$ & 16 & 27 & 15 & $5.06 e+04$ \\
\hline
\end{tabular}
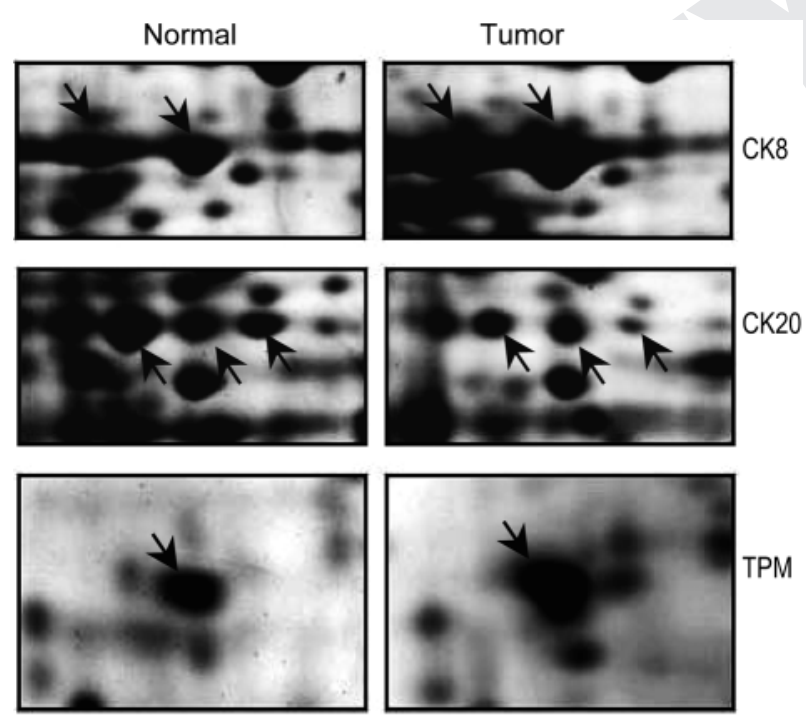

Figure 3. Detailed alteration patterns of CK proteins (CK8, CK20, and TPM).

antitrypsin ( $\alpha 1-A T)$ and apolipoprotein A1 (ApoA1) were obviously suppressed in gastric cancer. The phenomenon of diverse alteration also occurred with proteins involved in cell proliferation (Fig. 6). In contrast to the underexpression of GMP reductase 2 (GMPR), creatine kinase $B$ (CK-B) and selenium binding protein 1 (SeBP), an increased level of prohibitin was detected in gastric can-

(C) 2004 WILEY-VCH Verlag GmbH \& Co. KGaA, Weinheim cer. The significant down-regulation of the metabolism enzymes, carbonic anhydrase (CA) I and II, and a stomach specific protein, AMP-18, comprise the final protein alterations observed in the present gastric cancer study (Fig. 7).

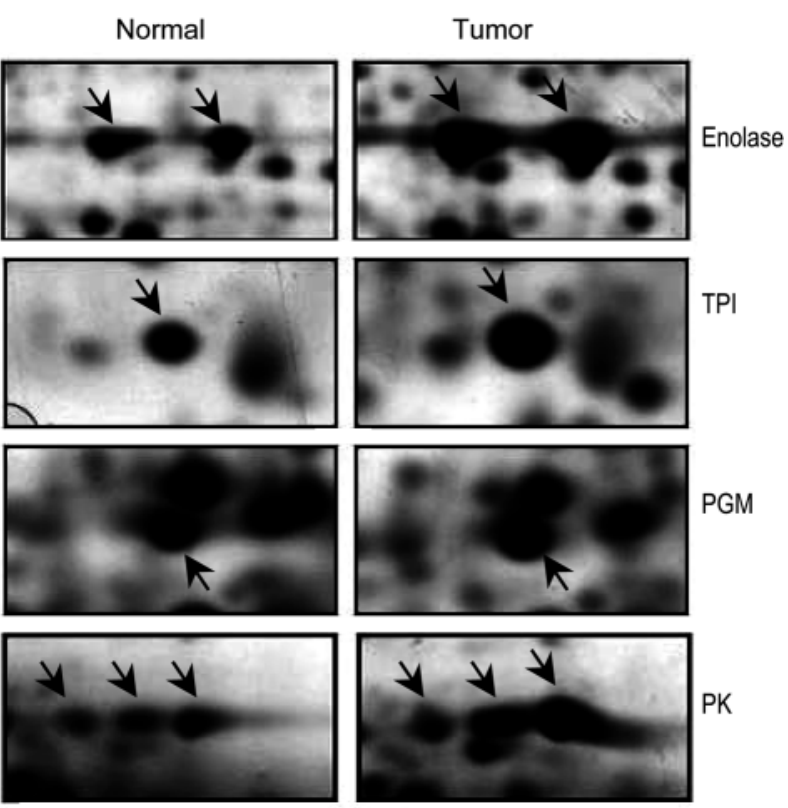

Figure 4. Detailed alteration patterns of glycolytic enzymes, enolase (TPI, PGM, and PK).

www.proteomics-journal.de 


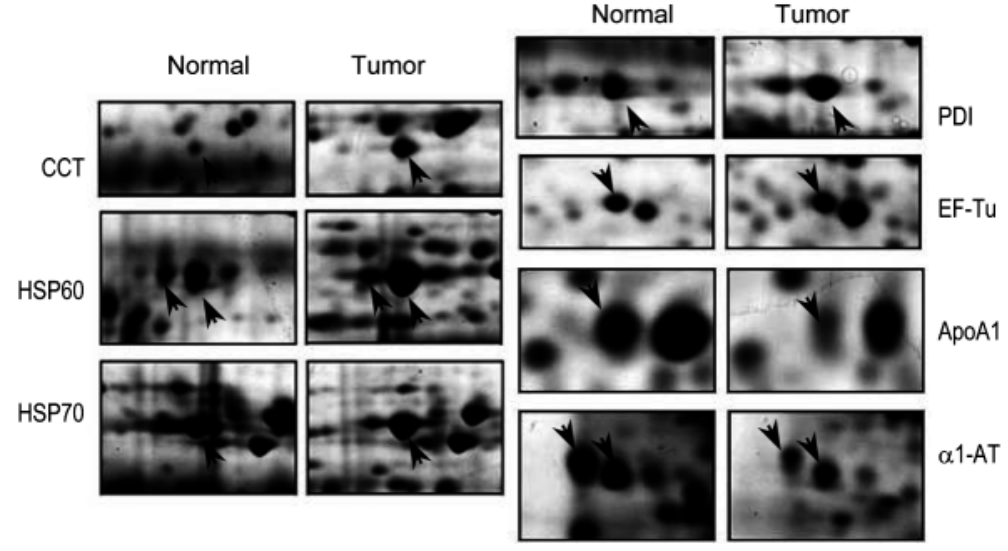

Figure 5. Detailed alteration patterns of chaperonin proteins (chaperonin containing TCP1 (CCT), HSP60, HSP70) PDI and EF-Tu, and acute-phase proteins (ApoA1 and $\alpha 1-A T)$.

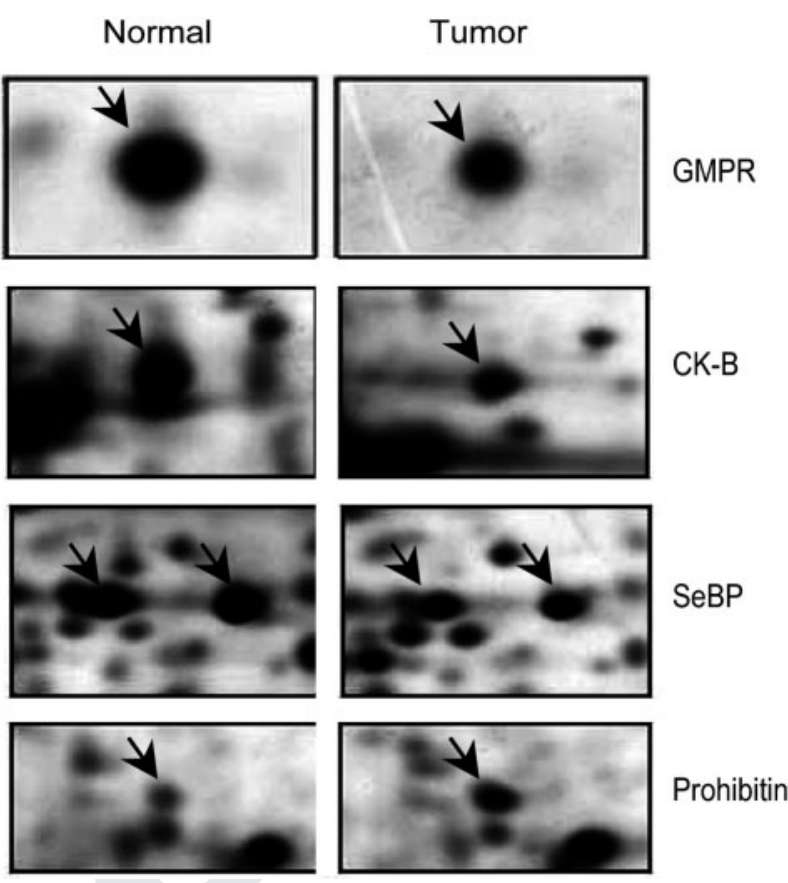

Figure 6. Detailed alterations of proteins involved in cell proliferation (GMPR, CK-B, SeBP, and prohibitin).
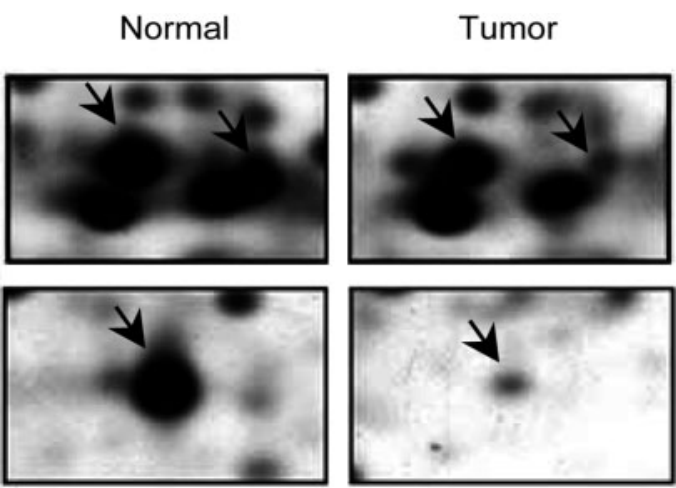

CA-I

AMP-18

Figure 7. Detailed alteration patterns of CA-I and CA-II and AMP-18.

(C) 2004 WILEY-VCH Verlag GmbH \& Co. KGaA, Weinheim

\subsection{Protein confirmation by 2-D Western blotting}

2-D Western blotting was carried out to confirm the protein identification of HSP60 and $\alpha 1$-AT which had database matching scores lower than 200 , enolase that has typical isoforms and AMP-18, the specific stomach protein. Figure 8 displays the protein spots with silver-staining and Western blotting side by side. Specific and positive immunochemical interactions occurred for the four proteins evaluated. Similar patterns of protein isoforms were observed with both silver-staining and Western blotting for all the proteins.
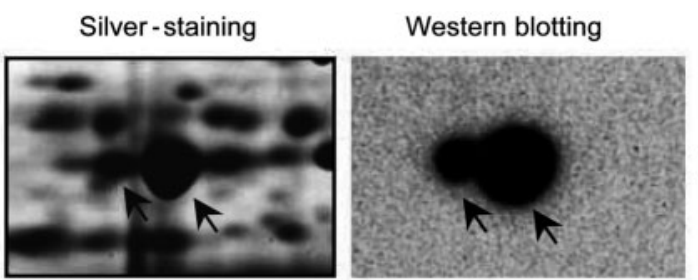

HSP60
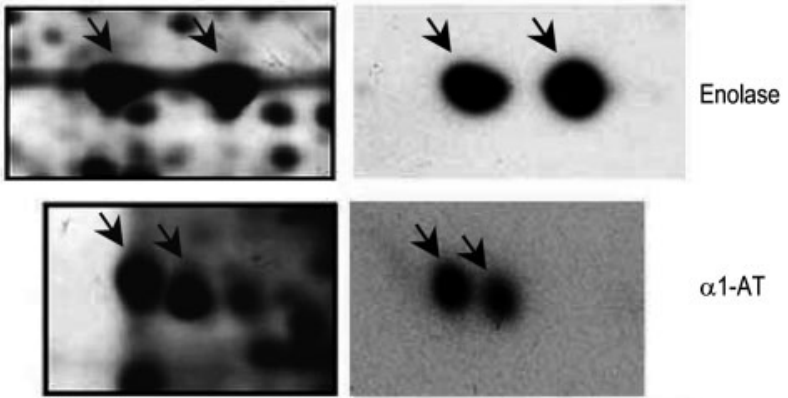

$\alpha 1-\mathrm{AT}$
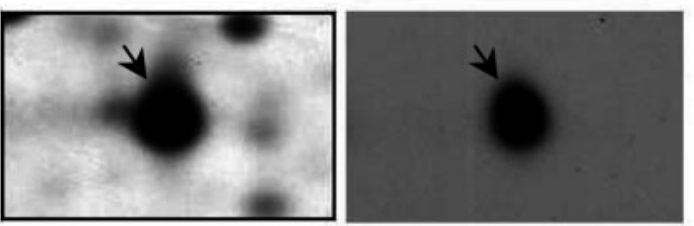

AMP-18

Figure 8. Protein confirmation by Western blotting for HSP60, enolase, $\alpha 1-A T$ and AMP-18.

www.proteomics-journal.de

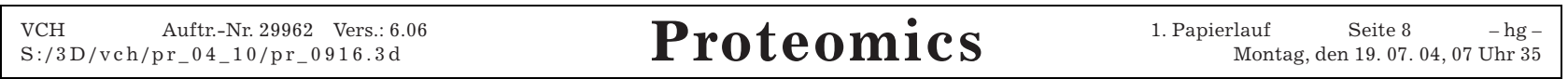




\subsection{Enzyme activity assessment}

Enzyme activities of three glycolytic enzymes (enolase, TPI and PGM) were assessed to compare their activities in both normal and tumor gastric tissues. To simplify the procedure, protein mixtures with equal aliquots from each normal and tumor tissue extract were used in the assessment. Table 4 lists the enzyme activities of the three proteins in paired tissue samples. Evidently, these glycolytic enzymes have activities 1-3-fold higher in tumor than in nontumor tissues, corresponding to the higher expressions of the proteins in tumor compared to control tissues.

Table 4. Activity levels of glycolytic enzymes in gastric normal tissue and adenocarcinoma

\begin{tabular}{lll}
\hline Enzyme & Normal tissue $(\mathrm{U} / \mathrm{g})$ & Tumor tissue $(\mathrm{U} / \mathrm{g})$ \\
\hline Enolase & 3.65 & 5.43 \\
TPI & 1.67 & 4.78 \\
PGM & 1.80 & 3.53 \\
\hline
\end{tabular}

\subsection{Tissue immunohistochemistry staining}

Since AMP-18 is a stomach specific protein and has the most significant expression change in gastric cancer, this protein was selected for immunohistochemistry staining in tissue samples to further validate its altered expression. Figure 9 is a typical AMP-18 antibody staining picture, clearly indicating the strong positive staining in the nontumor cells (left) and the negative staining in the matched tumor cells (right).

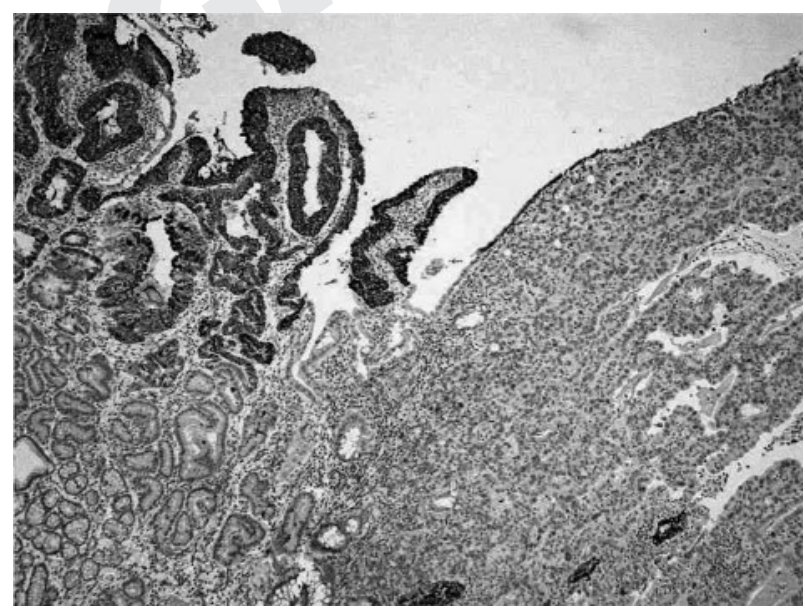

Figure 9. Immunohistochemical staining for AMP-18 showed strong positive staining in the foveolar antral mucosal cells (left side) but was completely negative in the gastric carcinoma cells (right side).

\section{Discussion}

As in most cancers, tumorigenesis of gastric adenocarcinoma involves multiple steps and factors [26]. It is therefore not surprising that many proteins performing various functional processes were found to be differently expressed between tumor and nontumor tissues. A common expression alteration in cancers occurs with cytoskeletal and structural proteins. Tropomyosin is a cytoskeletal microfilament binding protein. Many studies have shown that different tropomyosin isoforms perform distinct physiological roles, allowing isoform specific regulation in response to cell transformation [27, 28]. High $M_{r}$ tropomyosin isoforms were suppressed whereas low $M_{r}$ isoforms were up-regulated in cancers and transformed cells $[20,29,30]$. The observed over-expression of the low $M_{r}$ tropomyosin isoform $(29 \mathrm{kDa})$ suggests that tropomyosin-related cell transformation was also involved in gastric cancer.

CKs are main structural proteins in epithelial cells. They comprise the intermediate filaments of the cytoskeleton and are expressed in various combinations depending on the epithelial type and the degree of differentiation. The various and restricted expressions of CKs can help in determining the origin of many epithelial tumors and thus CKs are potential diagnostic and prognostic biomarkers for epithelial cancers including those in the gastrointestinal tract $[31,32]$. A CK7+/CK20- immunophenotype has been suggested to be a useful diagnostic tool for classifying oesophageal adenocarcinoma [31, 33] and especially for discriminating primary carcinomas from metastatic cancers of colon and gastric origins [34, 35]. On the other hand, cancer cells are known to secrete CK8-containing protein complex in vitro and in vivo [36]. Positive correlations have been demonstrated between high levels of CK8 expression and increased migration and invasion of certain cancer cells [36]. In particular, CK8 was found to be highly expressed in ductal and other gastrointestinal malignances $[37,38]$. The detected up-regulation of CK8 and down-regulation of CK20 in this study confirm the diversified expression of different cytokeratins, which may be used to specifically define gastric cancers.

Another interesting observation is the co-up-regulation of the four glycolytic enzymes, TPI, PGM, enolase and PK (Fig. 4), which are involved in the triose stage of the glycolytic pathway. In glycolysis, glucose is converted to pyruvate which is accompanied by the net production of two molecules of ATP. This energy-generating pathway is active in all differentiated cell types in multicellular organisms. Over-expression of glycolytic enzymes may be a reflection of active glycolysis, producing energy for the growth of gastric tumor cells. The fact that enolase, TPI and PGM have higher enzyme activities in gastric tumor 
than in normal tissue confirms the increased energy generation during carcinogenesis. Moreover, higher enzymatic activities of PGM and enolase have been detected in various tumor tissues including lung, colon, liver and breast carcinoma [21, 25, 39]. Significant over-expression of TPI has also been found in lung adenocarcinoma [40] and in squamous cell carcinoma of the bladder [41]. Our observation of increased expression of glycolytic enzymes in gastric cancer strengthens the association between glycolysis and carcinogenesis.

Numourous studies in vivo and in vitro have shown that the production of HSPs are transiently increased in response to harmful insults such as environmental stresses and infection [42]. Increased expression of HSPs has proven to have protective effects in cells and tissues, due to the capacity of HSPs to function as molecular chaperones to regulate appropriate protein folding and packaging. The over-expression of a group of HSPs including HSP70, HSP60 and CCT found in the present gastric tumor tissues (Fig. 5) may reflect the stress response and self-protective effort of the cells during malignant transformation. CCT is a cytosolic molecular chaperone that assists in the folding of actin, tubulin, and other proteins. It is a member of the HSP60 family. Although similar enhanced expression has been observed for HSP70 in gastric cancer [43-45], HSP60 in H. pylorirelated gastric carcinoma $[46,47]$ and CCT in colonic cancer cells [48], the simultaneous up-regulation of these HSPs makes perfect mechanistic sense. In many cellular processes, HSPs work cooperatively to fulfill their functions as molecular chaperones. Research has shown that HSP70 acts to promote substrate binding to CCT [49] and to pass the newly synthesized, unfolded proteins to HSP60 for final polypeptide folding [42].

Two other up-regulated proteins that have molecular chaperone functions are PDI and EF-Tu (Fig. 5). PDI is a multifunctional redox chaperone in the endoplasmic reticulum [50]. Due to its ability to catalyze the oxidation, reduction and isomerization of protein disulfides, PDI plays a role in the regulation of receptor function, cell-cell interaction, gene expression and actin filament polymerization. Considering its activity as a chaperone involved in the proper folding and formation of proteins, it is reasonable that PDI expression is often up-regulated under stress conditions. For example, elevated expression of PDI has been found in mouse F9 teratocarcinoma cells treated with retinoic acid and dibutyryl cAMP [51], in primary-cultured glial cells in response to hypoxia [52], in human prostate epithelial tumor cells subjected to ionizing radiation-induced apoptosis [53] and in human breast ductal carcinoma tissues [54]. EF-Tu also displays PDI activity and chaperone-like properties $[55,56]$, in addition to its known role in translation elongation. It is therefore no surprise that increased EF-Tu expression was observed in response to heat stress in maize line [57] and ischemiareperfusion injury in rat hearts [58]. Overall, our present findings indicate that coordinated regulation of molecular chaperones exists in gastric carcinoma.

In contrast to the increased expression of chaperone proteins, decreased expression was observed for the acutephase proteins $\alpha 1-A T$ and ApoA1 (Fig. 5). Acute-phase proteins are produced mainly by the liver in response to inflammation or a toxic challenge [59]. They $\boldsymbol{~ p l e a s e ~}$ rewrite sentence $\mathbf{a r e}$ individually regulated in different inflammatory conditions, presenting in enhanced (positive) or suppressed (negative) expression in plasma [59, $60]$. ApoA1 is a negative acute-phase protein. The current observation, together with a similar finding from a recent study [19], indicates that this negative acute response can also be found in tissues of gastric cancer. On the other hand, $\alpha 1-A T$, as a positive acute-phase protein, usually increased expression during inflammatory stress and carcinogenesis, reflecting its protective property by inhibiting apoptosis and caspase activity [61]. The observed under-expression of $\alpha 1$-AT therefore appears in controversy. However, the same phenomenon of a1-AT down-regulation in gastric cancer has been recently reported [19]. The underlying mechanism may be unique and interesting.

Diverse alterations also occurred with proteins involved in cell proliferation (Fig. 6). CK-B and GMPR are enzymes that promote cell differentiation [62, 63]. The expression of CK-B has been long related to malignant tumors of the gastrointestinal tract $[64,65]$. The down-regulation of these two enzymes may reflect the poor differentiation state at the late stages of gastric cancer. In contrast, the observed up-regulation of prohibitin is a reciprocal indicator for the inhibition of cell proliferation. Prohibitin has been shown to be a potential tumor suppressor protein and its increased levels have been found in various carcinomas [66-68]. Accumulating evidence (see review article [69]) convincingly demonstrated that selenium is a growth inhibitor and can prevent tumor cell growth. Recently Yang and Sytkowski [70] also showed that human selenium-binding protein gene (hsp56) was differently expressed in prostate cancer cells. The protein is expressed in the slow-growing prostate cancer cell line $\mathrm{LNCaP}$ but not in the rapidly growing cancer cells PC-3 and Du145. These results support our finding of underexpression of SeBP in gastric adenocarcinoma.

$\mathrm{CA}$ is a zinc-containing enzyme with nine isoforms that catalyze the hydration of $\mathrm{CO}_{2}$ for intermediate metabolism and to maintain $\mathrm{pH}$ and ion equilibrium in the body [71]. Although the presence of the enzyme has been prov- 
en essential in almost every organ, no evidence has so far been found to show a direct relationship between malignant transformation and CA expression for CAs I through VII [71]. Nevertheless, two earlier studies revealed that the expression of both CA-I and CA-II was significantly reduced in colorectal tumors when compared to normal colorectal epithelium or mucosa $[72,73]$. This was supported by the finding that CA-I mRNA was considerably reduced in colon carcinoma [74]. A recent report also presented results showing that reduced expression of CA-I and CA-II correlated with the biological aggressiveness of colorectal cancer and synchronous distant metastasis [75]. The decreased expression levels of CA-I and -II in the present gastric tumor tissues reveal a similar correlation, implying that gastric and colorectal carcinomas may share a similar mechanism of cell proliferation and mucosa malignancy.

More interestingly, AMP-18, a recently identified gastricspecific protein [76, 77], was found to be dramatically down-regulated in cancer tissues (Fig. 7). The gastric cDNA, CA11, which encodes an amino acid sequence that differs from AMP-18 in only a single residue [78, 79], should refer to the gene that produces the same protein, AMP-18. Both CA11 gene and AMP-18 were found to be intensively expressed in normal stomach tissue but not in most gastric cancers [76, 78, 79]. Immunohistochemical studies demonstrated that AMP-18 appears to be present in mucosal epithelial cells of normal human gastric antrum and duodenum [76]. AMP-18 is a growth factor at least partly responsible for maintaining normal functional gastric epithelium [76]. Our current data further validate the high expression of AMP-18 in both normal antrum and stomach body tissues and the substantial suppression of the protein in gastric adnocarcinoma, indicating that AMP-18 growth factor participates in the maintainence of normal differentiation and the growth of gastric mucosal epithelium but not in tumor cells after neoplastic transformation. In addition, this protein has been suggested to be a secreted rather than an integral membrane protein [79], implying that the protein may also be detected in serum. If so, a substantial decease of AMP-18 in patients' sera compared to the average level of the protein in normal serum may be informative for the assessment of gastric cancer.

\section{Concluding remarks}

In conclusion, multiple alterations in protein expression were detected in gastric adenocarcinoma. Some of these protein alterations were confirmed by immunochemical reactions or correlated with enzyme activities corresponding to the changes. Overall, gastric carcinogenesis involved protein alterations that occur in malignant transformation such as variations in cytoskeletal proteins, acute-phase proteins, molecular chaperones and energy-producing enzymes. Gastric cancer also involved tumor-associated proteins that presented a unique pattern of variation. In particular, a stomach specific protein, AMP-18, was found to be greatly down-regulated in gastric adenocarcinoma. Further combination evaluation by simultaneously considering these altered factors may result in an effective index for the assessment of the disease, and may also provide in-depth information for better understanding the pathogenesis of gastric cancer.

This work was partially supported by Hong Kong Research Grants Council Grants HKU 7227/02M (to Q.Y.H.), HKU 7218/02M and HKU 7395/03M (to J.F.C.), the Department of Chemistry, and the Areas of Excellence scheme of the Hong Kong University Grants Committee. We thank Ms. Yuan Zhou for technical assistance.

\section{References}

[1] Parkin, D. M., Bray, F., Ferlay, J., Pisani, P., Int. J. Cancer 2001, 94, 153-156.

[2] Pisani, P., Bray, F., Parkin, D. M., Int. J. Cancer 2002, 97, 72-81.

[3] Pisani, P., Parkin, D. M., Bray, F., Ferlay, J., Int. J. Cancer 1999, 83, 18-29.

[4] Ebert, M. P., Yu, J., Sung, J. J., Malfertheiner, P., Eur. J. Gastroenterol. Hepatol. 2000, 12, 795-798.

[5] Konturek, P. C., Kania, J., Konturek, J. W., Nikiforuk, A. et al., Med. Sci. Monit. 2003, 9, SR53-SR66.

[6] Peddanna, N., Holt, S., Verma, R. S., Anticancer Res. 1995, 15, 2055-2064.

[7] He, Q. Y., Chiu, J. F., J. Cell Biochem. 2003, 89, 868-886.

[8] Zhu, H., Bilgin, M., Snyder, M., Annu. Rev. Biochem. 2003, 72, 783-812.

[9] Petricoin, E. F., Liotta, L. A., J. Nutr. 2003, 133, 2476S2484S.

[10] McGregor, E., Dunn, M. J., Hum. Mol. Genet. 2003, 12 Spec. No 2, R135-R144.

[11] Denslow, N., Michel, M. E., Temple, M. D., Hsu, C. Y. et al., J. Neurotrauma 2003, 20, 401-407.

[12] Baak, J. P., Path, F. R., Hermsen, M. A., Meijer, G. et al., Eur. J. Cancer 2003, 39, 1199-1215.

[13] Ha, G. H., Lee, S. U., Kang, D. G., Ha, N. Y. et al., Electrophoresis 2002, 23, 2513-2524.

[14] Tomlinson, A. J., Hincapie, M., Morris, G. E., Chicz, R. M., Electrophoresis 2002, 23, 3233-3240.

[15] Sinha, P., Hutter, G., Kottgen, E., Dietel, M. et al., J. Biochem. Biophys. Methods 1998, 37, 105-116.

[16] Sinha, P., Poland, J., Schnolzer, M., Celis, J. E. et al., Electrophoresis 2001, 22, 2990-3000.

[17] Nilsson, C. L., Larsson, T., Gustafsson, E., Karlsson, K. A. et al., Anal. Chem. 2000, 72, 2148-2153.

[18] Haas, G., Karaali, G., Ebermayer, K., Metzger, W. G. et al., Proteomics 2002, 2, 313-324.

[19] Ryu, J. W., Kim, H. J., Lee, Y. S., Myong, N. H. et al., J. Korean Med. Sci. 2003, 18, 505-509. 
[20] He, Q. Y., Chen, J., Kung, H. F., Yuen, A. P. et al., Proteomics 2004, 4, 271-278.

[21] Durany, N., Joseph, J., Jimenez, O. M., Climent, F. et al., Br. J. Cancer 2000, 82, 20-27.

[22] He, Q. Y., Lau, G. K., Zhou, Y., Yuen, S. T. et al., Proteomics 2003, 3, 666-674.

[23] Bergmeyer, H. U. in: $\mathbf{\square}$ editors $\mathbf{\square}$, Methods of Enzymatic Analysis, 2nd Edn., Academic Press, New York, USA 1974 pp. $\square$ page numbers

[24] Durany, N., Joseph, J., Cruz-Sanchez, F. F., Carreras, J., Br. J. Cancer 1997, 76, 1139-1149.

[25] Durany, N., Joseph, J., Campo, E., Molina, R. et al., Br. J. Cancer 1997, 75, 969-977.

[26] Ming, S. C., Gastric. Cancer 1998, 1, 31-50.

[27] Gunning, P., Weinberger, R., Jeffrey, P., Anat. Embryol. (Berl) 1997, 195, 311-315.

[28] Braverman, R. H., Cooper, H. L., Lee, H. S., Prasad, G. L., Oncogene 1996, 13, 537-545.

[29] Novy, R. E., Lin, J. L., Lin, C. S., Lin, J. J., Cell Motil. Cytoskeleton 1993, 25, 267-281.

[30] Matsumura, F., Lin, J. J., Yamashiro-Matsumura, S., Thomas, G. P. et al., J. Biol. Chem. 1983, 258, 13954-13964.

[31] Ormsby, A. H., Goldblum, J. R., Rice, T. W., Richter, J. E. et al., Histopathology 2001, 38, 307-311.

[32] Scheuemann, P., Hosch, S. B., Izbicki, J. R., Dis. Esophagus. 2001, 14, 85-90.

[33] Taniere, P., Borghi-Scoazec, G., Saurin, J. C., LombardBohas, C. et al., Am. J. Surg. Pathol. 2002, 26, 1213-1221.

[34] Tot, T., Eur. J. Cancer 2002, 38, 758-763.

[35] Wauters, C. C., Smedts, F., Gerrits, L. G., Bosman, F. T. et al., Hum. Pathol. 1995, 26, 852-855.

[36] Gonias, S. L., Hembrough, T. A., Sankovic, M., Front Biosci. 2001, 6, D1403-D1411.

[37] Herzig, K. H., Altmannsberger, M., Folsch, U. R., Gastroenterology 1994, 106, 1326-1332.

[38] Lam, K. Y., Loke, S. L., Shen, X. C., Ma, L. T., Virchows Arch. 1995, 426, 345-349.

[39] Usuba, T., Ishibashi, Y., Okawa, Y., Hirakawa, T. et al., Int. J. Cancer 2001, 94, 662-668.

[40] Chen, G., Gharib, T. G., Huang, C. C., Thomas, D. G. et al., Clin. Cancer Res. 2002, 8, 2298-2305.

[41] Montgomerie, J. Z., Gracy, R. W., Holshuh, H. J., Keyser, A. J. et al., Clin. Biochem. 1997, 30, 613-618.

[42] Kiang, J. G., Tsokos, G. C., Pharmacol. Ther. 1998, 80, 183201.

[43] Isomoto, H., Oka, M., Yano, Y., Kanazawa, Y. et al., Cancer Lett. 2003, 198, 219-228.

[44] Canoz, O., Belenli, O., Patiroglu, T. E., Pathol. Oncol. Res. 2002, 8, 262-269.

[45] Maehara, Y., Oki, E., Abe, T., Tokunaga, E. et al., Oncology 2000, 58, 144-151.

[46] Kamiya, S., Yamaguchi, H., Osaki, T., Taguchi, H., J. Clin. Gastroenterol. 1998, 27 Suppl. 1, S35-S39.

[47] Yamaguchi, H., Osaki, T., Taguchi, H., Hanawa, T. et al., J. Gastroenterol. 1998, 33 Suppl. 10, 6-9.

[48] Yokota, S., Yamamoto, Y., Shimizu, K., Momoi, H. et al., Cell Stress. Chaperones. 2001, 6, 345-350.

[49] Melville, M. W., McClellan, A. J., Meyer, A. S., Darveau, A. et al., Mol. Cell Biol. 2003, 23, 3141-3151.
[50] Noiva, R., Semin. Cell Dev. Biol. 1999, 10, 481-493.

[51] Miyaishi, O., Kozaki, K., lida, K., Isobe, K. et al., J. Cell Biochem. 1998, 68, 436-445.

[52] Tanaka, S., Uehara, T., Nomura, Y., J. Biol. Chem. 2000, 275, 10388-10393.

[53] Prasad, S. C., Soldatenkov, V. A., Kuettel, M. R., Thraves, P. J. et al., Electrophoresis 1999, 20, 1065-1074.

[54] Bini, L., Magi, B., Marzocchi, B., Arcuri, F. et al., Electrophoresis 1997, 18, 2832-2841.

[55] Richarme, G., Biochem. Biophys. Res. Commun. 1998, 252, 156-161.

[56] Caldas, T. D., El Yaagoubi, A., Richarme, G., J. Biol. Chem. 1998, 273, 11478-11482.

[57] Bhadula, S. K., Elthon, T. E., Habben, J. E., Helentjaris, T. G. et al., Planta 2001, 212, 359-366.

[58] Sakai, J., Ishikawa, H., Kojima, S., Satoh, H. et al., Proteomics 2003, 3, 1318-1324.

[59] Gabay, C., Kushner, I., N. Engl. J. Med. 1999, 340, 448-454.

[60] Khovidhunkit, W., Memon, R. A., Feingold, K. R., Grunfeld, C., J. Infect. Dis. 2000, 181 Suppl. 3, S462-S472.

[61] Van Molle, W., Denecker, G., Rodriguez, I., Brouckaert, P. et al., J. Immunol. 1999, 163, 5235-5241.

[62] Zeng, G., Gao, L., Suetake, K., Joshi, R. M. et al., Cancer Lett. 2002, 178, 91-98.

[63] Zhang, J., Zhang, W., Zou, D., Chen, G. et al., J. Cancer Res. Clin. Oncol. 2003, 129, 76-83.

[64] Hirata, R. D., Hirata, M. H., Strufaldi, B., Possik, R. A. et al., Clin. Chem. 1989, 35, 1385-1389.

[65] Koven, I. H., Freedman, M., Miller, D., Reece, S. et al., Surgery 1983, 94, 631-635.

[66] Srisomsap, C., Subhasitanont, P., Otto, A., Mueller, E. C. et al., Proteomics 2002, 2, 706-712.

[67] Byrjalsen, I., Mose, L. P., Fey, S. J., Nilas, L. et al., Mol. Hum. Reprod. 1999, 5, 748-756.

[68] Williams, K., Chubb, C., Huberman, E., Giometti, C. S., Electrophoresis 1998, 19, 333-343.

[69] Harrison, P. R., Lanfear, J., Wu, L., Fleming, J. et al. , Biomed. Environ. Sci. 1997, 10, 235-245.

[70] Yang, M., Sytkowski, A. J., Cancer Res. 1998, 58, 31503153.

[71] Nogradi, A., Am. J. Pathol. 1998, 153, 1-4.

[72] Gramlich, T. L., Hennigar, R. A., Spicer, S. S., Schulte, B. A., Arch. Pathol. Lab Med. 1990, 114, 415-419.

[73] Mori, M., Staniunas, R. J., Barnard, G. F., Jessup, J. M. et al., Gastroenterology 1993, 105, 820-826.

[74] Sowden, J., Leigh, S., Talbot, I., Delhanty, J. et al., Differentiation 1993, 53, 67-74.

[75] Bekku, S., Mochizuki, H., Yamamoto, T., Ueno, H. et al., Hepatogastroenterology 2000, 47, 998-1001.

[76] Martin, T. E., Powell, C. T., Wang, Z., Bhattacharyya, S. et al., Am. J. Physiol Gastrointest. Liver Physiol. 2003, 285, G332G343.

[77] Toback, F. G., Walsh-Reitz, M. M., Musch, M. W., Chang, E. B. et al. , Am. J. Physiol Gastrointest. Liver Physiol 2003, 285, G344-G353.

[78] Yoshikawa, Y., Mukai, H., Hino, F., Asada, K. et al., Jpn. J. Cancer Res. 2000, 91, 459-463.

[79] Shiozaki, K., Nakamori, S., Tsujie, M., Okami, J. et al., Int. J. Oncol. 2001, 19, 701-707. 